\title{
Submerged macrophytes as a habitat for zooplankton development in two reservoirs of a flow-through system (Papuk Nature Park, Croatia)
}

\author{
Maria Špoljar ${ }^{*}$, Tvrtko Dražina ${ }^{1}$, Jasmina Šargač ${ }^{1}$, Koraljka Kralj Borojević ${ }^{2}$ and Petar Žutinić ${ }^{2}$ \\ ${ }^{1}$ Division of Zoology, Department of Biology, Faculty of Science, University of Zagreb, Rooseveltov trg 6, HR-10000 Zagreb, \\ Croatia \\ 2 Division of Botany, Department of Biology, Faculty of Science, University of Zagreb, Rooseveltov trg 6, HR-10000 Zagreb, Croatia
}

Received 10 January 2011; Accepted 18 October 2011

\begin{abstract}
In order to determine the influence of lentic habitats and macrophyte stands on the plankton development and seston flux, an investigation of zooplankton was carried out in the karst Jankovac flowthrough system (Papuk Nature Park, Croatia). The system was characterized by low abundance (1-116 ind. $\mathrm{L}^{-1}$ ) and high diversity of identified zooplankton. Eighty-six taxa were recorded, comprising 57 rotifers, 15 cladocerans, 8 copepods and 6 members of other groups of organisms. The spatial oscillations of environmental parameters and biocoenosis assemblage revealed statistically significant differences between lotic and lentic habitats, as well as between vegetated and non-vegetated stations. These differences mainly respond to higher concentration of food resources and zooplankton/zooseston abundance and biomass in lentic, especially vegetated, habitats. This is also proved by results of principal component analysis (PCA), which suggested that the main drivers of development of the planktonic community were the food resources and the avoidance of flow velocity. Accordingly, shoreline areas with submerged macrophyte stands of Hippuris vulgaris L. were the most productive parts, represented by highest zooplankton abundance, biomass and biodiversity. Flow velocity significantly affected crustaceans assemblage, so that higher abundances of the larger cladocerans and copepods were achieved in vegetated stations with low flow velocity, while rotifers showed to be rheotolerance organisms. On the other hand, the longitudinal discontinuum of the stream channel by two man-made reservoirs could offer new habitats to enrich seston with organic particles and bioseston. The results of our study pronounce the need for further monitoring of this hydrosystem, especially considering biodiversity and microhabitats conservation.
\end{abstract}

Key words: Rotifers / cladocerans / copepods / karst stream / seston flux

\section{Introduction}

Freshwater ecosystems are often affected by different anthropogenic disturbances, which are mainly manifested through pollution, flow regime alteration, e.g. damming and, consequently, habitat destruction (Lair, 1980; El-Shabrawy and Dumont, 2003; Castro et al. 2005). Longitudinal discontinuities in running waters, such as lateral dams, reservoirs or riverine lakes can be a source of plankton (Lair and Reyes-Marchant, 1997; Basu et al., 2000; Spoljar et al., 2007b; Zimmermann-Timm et al., 2007). These lentic areas in a flow-through system play a role in organic matter production that latter on serves as food supplies for downstream benthic organisms

\footnotetext{
*Corresponding author: mspoljar@zg.biol.pmf.hr
}

(Sandlund, 1982; Hart and Finelli, 1999; Špoljar et al., 2007b).

Slow-flowing inshore habitats provide favourable conditions for development of extensive beds of aquatic macrophytes outside the mainstream channel (Basu et al., 2000). Macrophyte stands have multiple effects on aquatic ecosystems, such as reducing sediment suspension, preservation of physical stability of the littoral zone, reducing erosion processes, nutrient concentration and ameliorating eutrophication symptoms such as water turbidity (Horppila and Nurminen, 2005; Estlander et al., 2009). Also, macrophytes offer food supplies as well as refuge for zooplankton species from pelagial predators (Burks et al., 2001a; Kuczyńska-Kippen and Nagengast, 2006; Estlander et al., 2009). The availability of macrophytes as food resources and refuge depends on various factors 
including plant architecture, size and density of plant patches, and also, on the predators that these plants host (Jeppesen et al., 1997; Kuczyńska-Kippen, 2005; Meerhoff et al., 2007). Seeking daytime refuge from visual predator, i.e. fish, in shallow lakes, zooplankton shifts into the littoral vegetated area presenting diel horizontal migrations (Gliwicz and Rykowska, 1992; Lauridsen and Lodge, 1996; Meerhoff et al., 2006). In the littoral zone, zooplankton can be confronted with invertebrate predators including odonates, notonectids, dytiscid beetles and water mites, which exert a strong predation impact on zooplankton populations (Beklioglu and Jeppesen, 1999; Burks et al., 2001b; Meerhoff et al., 2007; GonzálezSagrario et al., 2009).

Our study was undertaken in the Jankovac Stream (Papuk Nature Park, Croatia), struck by anthropogenic hydromorphological impact that resulted in two reservoirs. As a consequence, lentic stretches occupy the majority of the stream length and consist of two manmade reservoirs covered by submerged vegetation, while lotic stretches are represented by the spring and waterfall area. In such a flow-through system, the existing seston (rheoseston) consists of organic dead or alive, and inorganic particles of both autochtonous and allochtonous origin (Breitig and von Tümpling 1982; Špoljar et al., 2007b). Zooseston represents its faunistic component. The majority of the particles and organisms in seston originate from the benthos (bed or periphyton) and/or the plankton (from upstream reservoirs). Thus, seston importance manifests as food resource for downstream benthic communities (Descy, 1993; Špoljar et al., 2007b; Zimmermann-Timm et al., 2007) and organisms dispersion (Sertić Perić et al., 2011).

In this study, we attempted to analyse the development of zooplankton community in reservoirs of a submountain flow-through system and its influence on downstream seston flux. Our survey considers primarily rotifers, cladocerans and copepods assemblages in two reservoirs in relation to two main factors: presence or absence of (a) macrophyte stands and (b) flow velocity. Thus, we anticipated that water current and possible fish predation more affect cladoceran's and copepod's shift to the littoral zone than rotifer's. Accordingly, we expected that rotifers, as rheotolerant organisms, would have substantial contribution to the downstream seston flux. The objectives of this study were to determine: (1) the influence of reservoirs on the development of the zooplankton community in the flow-through system; (2) the importance of shoreline macrophyte habitats for the zooplankton assemblages and (3) the influence of hydrological features on the seston flux.

\section{Study area}

This investigation was conducted in the Jankovac Stream situated on sedimentary rocks in the Papuk Nature Park, Croatia (Fig. 1). Jankovac is a small, approximately $700 \mathrm{~m}$ long, flow-through system in a submountain area at $475 \mathrm{~m}$ asl. (45 $\left.31^{\prime} 07^{\prime \prime} \mathrm{N}, 17^{\circ} 41^{\prime} 11^{\prime \prime} \mathrm{E}\right)$ in which two hydrologically different habitats, i.e. lentic and lotic, alternate. Across the longitudinal profile, the stream is mostly surrounded by deciduous forest at a distance of 10 to $2 \mathrm{~m}$, from mouth to spring, respectively. The main hydromorphometric features as well as the macrophyte composition of the study area and sampling stations are summarized in Table 1. The lotic stretches are represented by the rheocrene spring and adjacent hypocrenal area (JS sampling station) and the Skakavac waterfall over a tufa barrier that, at the same time, represents the mouth of the Jankovac Stream (JW sampling station). The majority of the streambed is lentic, which has shaped two man-made reservoirs. The stream inflows to the first reservoir (R1) after approximately $60 \mathrm{~m}$ of flow over a moss-covered bed. This reservoir is separated from the second one (R2) by a 2-m high bank, and water flows through a small connection between these reservoirs. Both reservoirs are polymictic with a maximum depth of $2 \mathrm{~m}$ and characterized by low phosphate (R1 $0.02 \pm 0.009 \mathrm{mg} \mathrm{PO}{ }_{4}^{3-}-\mathrm{P} . \mathrm{L}^{-1}, \mathrm{R} 20.02 \pm 0.01 \mathrm{mg} \mathrm{PO}_{4}^{3-}$ P.L $\left.{ }^{-1}, N_{\mathrm{R} 1, \mathrm{R} 2}=12\right)$ and higher nitrate (R1 $1.10 \pm 0.17 \mathrm{mg}$ $\mathrm{NO}_{3}^{-}-\mathrm{N} . \mathrm{L}^{-1}, \mathrm{R} 21.0 \pm 0.2 \mathrm{mg} \mathrm{NO}-{ }_{3}^{-}$N.L $\left.{ }^{-1}, N_{\mathrm{R} 1, \mathrm{R} 2}=12\right)$ concentrations. The reservoirs are not usually frozen in the winter or just thin ice cover appears sporadically during December to February. Transparency through the entire water column enables the growth of submerged macrophytes, Potamogeton natans L. and Hippuris vulgaris L., the latter mostly contributes to the coverage of reservoir's bottom. The littoral zones of both reservoirs are covered with narrow discontinued belt of emergent macrophyte species such as Carex sp., Scirpus sp., Iris pseudacorus L. and Typha latifolia L. Two different habitats can be identified within the reservoirs: non-vegetated (R1N and $\mathrm{R} 2 \mathrm{~N}$ ) and vegetated (R1M and R2M) areas. The outflow of the second reservoir is channelled and leads to the Skakavac waterfall (JW) which flows into the Kovačica stream and thereby belongs to Drava River watershed area.

From vertebrate predators newts and fish were presented. Newts were dominated by species Lissotriton vulgaris (L.) and less by Ichthyosauras alpestris (Laurenti) and Triturus carnifex (Laurenti). According to the ichthyological survey conducted during 2006 across the water bodies in Nature Park Papuk, in Jankovac Stream only lamprey, Lamperta planeri Bloch, and brown trout, Salmo trutta $\mathrm{L}$., with 25 and $75 \%$ in abundance, respectively, were identified (Mrakovčić et al., 2008). Detailed ichthyological examinations have not been conducted during field sampling, because these reservoirs belong to a protected area.

\section{Materials and methods}

Samples were collected on a monthly basis from May to October 2008. According to the currently accepted conception of seston, all our samples could be considered as zooseston, but we divided them into two groups. In lentic stretches, i.e. reservoirs, we considered samples as 


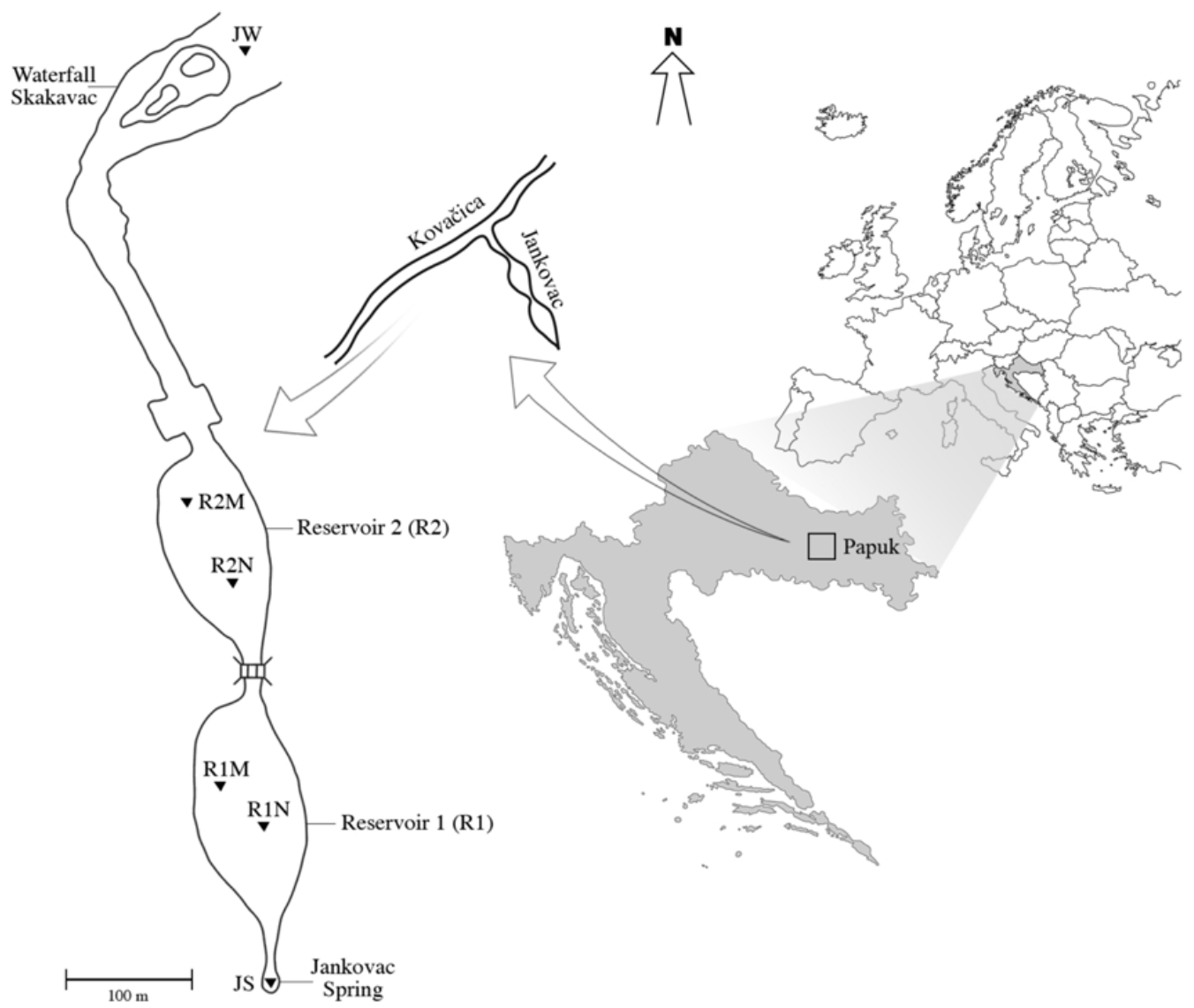

Fig. 1. Map of the Jankovac Stream flow-through system with sampling stations investigated marked.

zooplankton which were collected from two different habitat types, vegetated (R1M and R2M) and nonvegetated (R1N and $\mathrm{R} 2 \mathrm{~N}$ ). In lotic stretches, i.e. spring and waterfall, we considered samples as zooseston, which were taken from the spring station as inflow (JS) and from the waterfall station (JW) as the outflow of seston flux. In this study, difference between zooplankton and zooseston is terminological, but not methodological.

From each station, $50 \mathrm{~L}$ of water were filtered through a plankton net $(26 \mu \mathrm{m}$ mesh; 6 months $\times 6$ sites $\times 3$ replicates $=108$ samples). The samples were kept cool and transported to the laboratory in $200 \mathrm{~mL}$ bottles. A mean of triplicate was used as a single data point for a given date and site for further data analyses. Zooplankton/zooseston identification was carried out on live materials, which were later fixed in $4 \%$ formalin. The diversity and abundance in zooplankton/zooseston were assessed considering three groups of organisms: Rotifera, Cladocera and Copepoda. Rotifers were identified to the species or genus level according to Voigt and Koste (1978). Bdelloidea were counted, but not identified. Most crustaceans belonged to Cladocera and Copepoda and were identified to the genus or species level using the identification keys of Margaritora (1983) and Einsle (1993), while Ostracoda were not identified. Turbellaria, Nematoda, Gastrotricha, Oligochaeta, Tardigrada, Hydrachnidia and Ostracoda were not identified to the lower taxonomic level, but were classified as a heterogenic group of organisms. For quantitative analysis, the entire sample was counted using a Petri dish under an Opton-Axiovert 35 inverted microscope.

Biomass (dry weight, DW) of rotifers, cladocerans and copepods in seston was calculated according to the length-weight relationship for up to 30 randomly selected specimens per taxon (Dumont et al., 1975; Malley et al., 1989). Biomass in the heterogenic group of organisms was determined after being oven dried at $104{ }^{\circ} \mathrm{C}$. Measurements were carried out on up to 20 randomly selected specimens per taxon. We considered specimens from the genera Alona, Bosmina, Ceriodaphnia, Chydorus, Disparalona and Pleuroxus, as small bodied (length $500 \mu \mathrm{m}$ to $1 \mathrm{~mm}$ ) and species from genera Daphnia, Sida and Simocephalus as large bodied (length $>1-6 \mathrm{~mm}$ ).

The following parameters were measured in situ: temperature, dissolved oxygen concentration (WTW OXI 96), pH (WTW 330i), conductivity (HACH sension 5) and flow velocity (P600 flow meter, DOSTMANN electronic $\mathrm{GmbH})$. For analyses of chemical parameters and chlorophyll $a(\mathrm{Chl} a), 3 \mathrm{~L}$ of non-filtered water was collected in bottles from each study site as the zooseston/zooplankton samples $(6$ months $\times 6$ sites $\times 1$ sample $=36$ samples $)$. Total alkalinity was measured by acidimetry with methyl orange as an indicator and nitrates were quantified using the sodium salicylate method (Höll, 1986). The stannous chloride method was used for the measurement of phosphate according to APHA (1985). 
Table 1. Main morphometric features and macrophyte composition of the sampling stations on Jankovac Stream, Papuk Nature Park. WRT, water residence time.

\begin{tabular}{|c|c|c|c|c|c|c|}
\hline \multirow{2}{*}{$\begin{array}{l}\text { Localities } \\
\text { Coordinates }\end{array}$} & JS & $\mathrm{R} 1$ & & R2 & & JW \\
\hline & & $\begin{array}{l}45^{\circ} 31^{\prime} 09^{\prime \prime} \mathrm{N} \\
17^{\circ} 41^{\prime} 11^{\prime \prime} \mathrm{E}\end{array}$ & & $\begin{array}{l}45^{\circ} 31^{\prime} 14^{\prime \prime} \mathrm{N} \\
17^{\circ} 41^{\prime} 09^{\prime \prime} \mathrm{E}\end{array}$ & & \\
\hline Area $\left(m^{2}\right)$ & & 9240 & & 5317 & & \\
\hline $\operatorname{Length}_{\max }(\mathrm{m})$ & 61 & 168 & & 130 & & \\
\hline Width $_{\max }(\mathrm{m})$ & 3 & 52 & & 51 & & \\
\hline$z_{\max }(\mathrm{m})$ & 0.25 & 1.9 & & 1.95 & & 0.7 \\
\hline Height (m) & & & & & & 32 \\
\hline Total volume $\left(\mathrm{m}^{3}\right)$ & & $8.8 \times 10^{4}$ & & $6.8 \times 10^{4}$ & & \\
\hline WRT (day) & & 4.4 & & 3.4 & & \\
\hline $\begin{array}{l}\text { Sampling } \\
\text { stations }\end{array}$ & JS & $\mathrm{R} 1 \mathrm{~N}$ & $\mathrm{R} 1 \mathrm{M}$ & $\mathrm{R} 2 \mathrm{~N}$ & $\mathrm{R} 2 \mathrm{M}$ & JW \\
\hline $\begin{array}{l}\text { Habitat } \\
\text { specification }\end{array}$ & Lotic & Lentic & Lentic & Lentic & Lentic & Lotic \\
\hline $\begin{array}{l}\text { Flow velocity } \\
\left(\mathrm{m} \cdot \mathrm{s}^{-1}\right)\end{array}$ & $0.91 \pm 0.69$ & $0.16 \pm 0.10$ & Stagnant & $0.14 \pm 0.088$ & Stagnant & $1.38 \pm 1.03$ \\
\hline $\begin{array}{l}\text { Habitat } \\
\text { description }\end{array}$ & $\begin{array}{c}\text { Small pool } \\
\left(z_{\text {mean }}=0.15 \mathrm{~m},\right. \\
\varnothing 1.5 \mathrm{~m}) \text { on the } \\
\text { cave entrance, } c c a \\
3 \mathrm{~m} \text { after } \\
\text { spring, and } \\
\text { before } \\
\text { hypocrenal } \\
\text { area }\end{array}$ & $\begin{array}{c}\text { Reservoir, } \\
\text { non-vegetated }\end{array}$ & $\begin{array}{l}\text { Reservoir, } \\
\text { vegetated }\end{array}$ & $\begin{array}{l}\text { Reservoir, } \\
\text { non-vegetated }\end{array}$ & $\begin{array}{l}\text { Reservoir, } \\
\text { vegetated }\end{array}$ & $\begin{array}{c}\text { Small pool } \\
\left(\mathrm{z}_{\text {mean }}=0.5 \mathrm{~m},\right. \\
\varnothing 1.5 \mathrm{~m}), \text { after } \\
\text { waterfall and } \\
\text { bryophyte } \\
\text { covered barrier, } \\
\text { on the stream } \\
\text { mouth }\end{array}$ \\
\hline $\begin{array}{l}\text { Bottom } \\
\text { granulometry }\end{array}$ & Sand, detritus & Mud & Mud & Mud & Mud & Boulders, tufa \\
\hline $\begin{array}{l}\text { Bed and macrophyte } \\
\text { coverage } \%\end{array}$ & $\begin{array}{l}\text { Thin layer of } \\
\text { sediment }\end{array}$ & Non-vegetated & $\begin{array}{c}\text { Potamogeton } \\
\text { natans }(25 \%), \\
\text { Hippuris vularis } \\
(50 \%)\end{array}$ & Non-vegetated & $\begin{array}{l}\text { H. vularis } \\
(60 \%)\end{array}$ & $\begin{array}{l}\text { Thin layer } \\
\text { of sediment }\end{array}$ \\
\hline
\end{tabular}

Phytoplankton and particulate organic matter (POM) were considered as food resource for the main zooplanktonic groups as well as for benthic organisms. Chl $a$ concentration was estimated by ethanol extraction by Nusch (1980) and was used as an indicator of algal biomass. For DW and ash-free dry weight (AFDW) estimation, an additional $3 \mathrm{~L}$ of water was first filtered (Schleicher \& Schuell White Ribbon 589/2, ashless quantitative filter paper), then dried at $104{ }^{\circ} \mathrm{C}$ and ashed at $600{ }^{\circ} \mathrm{C} / 6$ h $\quad(6$ months $\times 6$ sites $\times 1$ sample $=36$ samples). DW was considered as the amount of total suspended matter (TSM), while AFDW was considered as an indicator of detritus or POM. The flux $(\mathrm{kg} / \mathrm{d})$ of TSM, POM and zooseston DW biomass was estimated as the product of related amounts and discharge.

The field data for the morphometric features of the sampling stations and flow velocity were used for the calculation of discharge and water residence time (WRT; Kalff, 2002). Macrophyte coverage (\%) was estimated from the ratio of transect length occupied by a particular macrophyte to total transect length in each reservoir (Lau and Lane, 2002).

Prior to statistical analysis, all abiotic and biotic data were logarithmically transformed $[\log (x+1)]$ and their normality was checked using Shapiro-Wilk's test. As this test suggested the data did not follow a normal distribution, a non-parametric Kruskal-Wallis test (comparison among multiple independent samples for environmental parameters and biotic components) or a Mann-Whitney $U$ test (comparison between two independent samples for environmental parameters and biotic components) were used. Data were correlated using Spearman rank. For KruskalWallis test, the post-hoc multiple comparison of average ranks was provided. The provided analyses reflected seasonal oscillations among, i.e. spring (May, June), summer (July, August) and autumn (September, October), as well as among investigated months, but no statistically significant differences were observed, except for temperature, nitrates and orthophosphates. Therefore, environmental parameters and biotic components were considered only through the spatial oscillations. For an explanation of the relationships between the abundance/ seston flux of the dominant zooplankton/zooseston taxa and environmental variables (flow velocity/discharge, conductivity, $\mathrm{pH}, \mathrm{Chl} a$ and AFDW), a multivariate method, the principal component analysis (PCA) was used. The interactions between biota and environmental parameters were presented by plotting the correlations of variables with the extracted PCA axes. For statistical data analyses, STATISTICA software package was used $\left(\right.$ StatSoft $\left.^{(}\right)$. 
Table 2. Minimum, maximum and mean values with noted statistically significant differences among investigated sampling stations for (a) environmental conditions and (b) biocoenosis diversity, abundance and biomass (Kruskal-Wallis test, $\mathrm{df}=5, N=36$ ), with accompanied results of post-hoc multiple comparison test. Abbreviations: TSM, total suspended matter; POM, particulate organic matter; DW, dry weight; AFDW, ash-free dry weight.

\begin{tabular}{|c|c|c|c|c|c|c|}
\hline & Mean \pm SD & Min & $\operatorname{Max}$ & $\bar{H}$ & $P$ & Multiple comparison test \\
\hline \multicolumn{7}{|l|}{ (a) Environmental conditions } \\
\hline Flow velocity $\left(\mathrm{m} . \mathrm{s}^{-1}\right)$ & $0.62 \pm 0.34$ & 0.01 & 1.50 & 25.33 & $* * *$ & $\mathrm{JS}, \mathrm{JW}>\mathrm{R} 1 \mathrm{~N}, \mathrm{R} 1 \mathrm{M}, \mathrm{R} 2 \mathrm{~N}, \mathrm{R} 2 \mathrm{M}$ \\
\hline Temperature $\left({ }^{\circ} \mathrm{C}\right)$ & $15.21 \pm 3.86$ & 9.40 & 21.60 & 10.69 & ns & \\
\hline Dissolved oxygen (mg.L $\mathrm{L}^{-1}$ ) & $11.39 \pm 2.40$ & 7.48 & 16.90 & 2.90 & ns & \\
\hline Conductivity $\left(\mu \mathrm{S} . \mathrm{cm}^{-1}\right)$ & $461.19 \pm 29.63$ & 388.00 & 521.00 & 25.17 & $* * *$ & $\mathrm{JW}<\mathrm{JS}, \mathrm{R} 1 \mathrm{~N}$ \\
\hline $\mathrm{pH}$ & $7.78 \pm 0.30$ & 7.23 & 8.43 & 24.82 & $* * *$ & $\mathrm{JW}>\mathrm{JS}, \mathrm{R} 1 \mathrm{~N}$ \\
\hline Free $\mathrm{CO}_{2}\left(\mathrm{mg} \cdot \mathrm{CO}_{2} \cdot \mathrm{L}^{-1}\right)$ & $8.46 \pm 4.00$ & 2.20 & 17.60 & 19.72 & $* *$ & $\mathrm{JS}>\mathrm{R} 2 \mathrm{M}, \mathrm{JW}$ \\
\hline Alkalinity $\left(\mathrm{mg} \mathrm{CaCO} 3 \cdot \mathrm{L}^{-1}\right)$ & $243.29 \pm 14.29$ & 205.00 & 275.00 & 25.18 & $* * *$ & $\mathrm{JW}<\mathrm{JS}, \mathrm{R} 1 \mathrm{~N}, \mathrm{R} 1 \mathrm{M} ; \mathrm{R} 2 \mathrm{~N}<\mathrm{JS}$ \\
\hline Nitrates, $\mathrm{NO}_{3}^{-}-\mathrm{N}\left(\mathrm{mg}^{-\mathrm{L}^{-1}}\right)$ & $1.12 \pm 0.28$ & 0.72 & 1.77 & 17.65 & $* *$ & $\mathrm{JS}>\mathrm{R} 2 \mathrm{~N}, \mathrm{R} 2 \mathrm{M}, \mathrm{JW}$ \\
\hline Orthophosphates, $\mathrm{PO}_{3}^{-}-\mathrm{P}\left(\mathrm{mg} \cdot \mathrm{L}^{-1}\right)$ & $0.03 \pm 0.01$ & 0.01 & 0.06 & 2.18 & ns & \\
\hline Chl $a\left(\mu \mathrm{g} . \mathrm{L}^{-1}\right)$ & $1.07 \pm 1.15$ & 0.01 & 4.32 & 17.23 & $* *$ & $\mathrm{JS}<\mathrm{R} 1 \mathrm{M}, \mathrm{R} 2 \mathrm{~N}, \mathrm{R} 2 \mathrm{M}$ \\
\hline TSM (DW mg.m ${ }^{-3}$ ) & $9.18 \pm 29.42$ & 0.97 & 174.60 & 19.64 & $* *$ & $\mathrm{JS}<\mathrm{R} 1 \mathrm{M}, \mathrm{R} 2 \mathrm{M}$ \\
\hline POM (AFDW mg.m ${ }^{-3}$ ) & $6.09 \pm 28.40$ & 0.25 & 171.20 & 22.11 & $* * *$ & $\begin{array}{l}\mathrm{JS}<\mathrm{R} 1 \mathrm{M}, \mathrm{R} 2 \mathrm{M} ; \mathrm{R} 1 \mathrm{~N}<\mathrm{R} 1 \mathrm{M} \\
\mathrm{R} 1 \mathrm{M}>\mathrm{R} 2 \mathrm{M}\end{array}$ \\
\hline \multicolumn{7}{|c|}{ (b) Biocoenosis diversity, abundance and biomass } \\
\hline Biodiversity (taxa number) & $13.92 \pm 6.78$ & 1.00 & 28.00 & 18.89 & $* *$ & $\mathrm{JS}<\mathrm{R} 1 \mathrm{M}$ \\
\hline Rotifers (Ind. $\mathrm{L}^{-1}$ ) & $10.40 \pm 14.22$ & 0.11 & 73.21 & 20.39 & $* * *$ & $\mathrm{JS}<\mathrm{R} 1 \mathrm{M}, \mathrm{R} 2 \mathrm{~N}, \mathrm{JW}$ \\
\hline Cladocerans (Ind.L ${ }^{-1}$ ) & $3.51 \pm 11.13$ & 0.01 & 59.36 & 16.72 & $* *$ & $\mathrm{JS}<\mathrm{R} 1 \mathrm{M} ; \mathrm{R} 1 \mathrm{M}>\mathrm{R} 2 \mathrm{~N}$ \\
\hline Copepods (Ind. $\mathrm{L}^{-1}$ ) & $2.51 \pm 5.09$ & 0.01 & 23.64 & 24.24 & $* * *$ & $\mathrm{JS}<\mathrm{R} 1 \mathrm{M}, \mathrm{R} 2 \mathrm{M}$ \\
\hline Total zooseston $\left(\right.$ Ind.L ${ }^{-1}$ ) & $16.71 \pm 24.76$ & 0.11 & 122.36 & 24.24 & $* * *$ & $\mathrm{JS}<\mathrm{R} 1 \mathrm{M}, \mathrm{R} 2 \mathrm{M}, \mathrm{JW}$ \\
\hline Rotifers $\left(\mu \mathrm{g} . \mathrm{L}^{-1}\right)$ & $1.59 \pm 2.74$ & 0.01 & 12.14 & 20.86 & $* * *$ & $\mathrm{JS}<\mathrm{R} 2 \mathrm{~N}, \mathrm{R} 2 \mathrm{M}$ \\
\hline Cladocerans ( $\mu$ g. $\left.\mathrm{L}^{-1}\right)$ & $20.51 \pm 57.41$ & 0.01 & 300.50 & 18.26 & $* *$ & $\mathrm{JS}<\mathrm{R} 1 \mathrm{M}$ \\
\hline Copepods $\left(\mu \mathrm{g} . \mathrm{L}^{-1}\right)$ & $5.18 \pm 11.24$ & 0.01 & 52.33 & 22.54 & $* * *$ & $\mathrm{JS}<\mathrm{R} 1 \mathrm{M}, \mathrm{R} 2 \mathrm{M}$ \\
\hline Total zooseston $\left(\mu \mathrm{g} . \mathrm{L}^{-1}\right)$ & $33.35 \pm 67.60$ & 0.01 & 357.03 & 18.61 & $* *$ & $\mathrm{JS}<\mathrm{R} 1 \mathrm{M}, \mathrm{R} 2 \mathrm{M}$ \\
\hline
\end{tabular}

$* P<0.05 ; * * P<0.005 ; * * * P<0.001$

\section{Results}

\section{Environmental parameters in the Jankovac flow-through system}

Among the sampling stations, significant differences were observed for the majority of measured parameters except for temperature, dissolved oxygen and orthophosphate (Table 2a). Across the longitudinal profile, the temperature was lowest $\left(10.95 \pm 2.15{ }^{\circ} \mathrm{C}\right)$, but the concentration of dissolved oxygen was the highest $\left(12 \pm 2.5 \mathrm{mg} \mathrm{O}_{2} . \mathrm{L}^{-1}\right)$ at JS. Higher oxygen concentrations were also observed in the vegetated areas of both reservoirs with higher photosynthetic activity of submerged macrophytes (R1M $12 \pm 2.9 \mathrm{mg} \mathrm{O}_{2} . \mathrm{L}^{-1}$; R2M $\left.11.8 \pm 2.8 \mathrm{mg} \mathrm{O}_{2} . \mathrm{L}^{-1}\right)$, but these differences were not significant $(P>0.05)$. As expected, temperature showed significant seasonal differences (Kruskal-Wallis test, $N=36, H=16.90, P=0.002)$ with higher values in summer and autumn (post-hoc test, $P=0.0001$ ).

Flow velocity was obviously higher in lotic (JS and JW) than in lentic (R1N, R1M, R2N and R2M) stations. The parameters indicating the water-buffering capacity, free $\mathrm{CO}_{2}$, alkalinity and conductivity showed negative, while $\mathrm{pH}$ showed positive longitudinal gradient. Most of these results were caused by the differences between JS and JW, as confirmed by post-hoc test (Table 2a).

Nitrates (Kruskal-Wallis test, $N=36, \quad H=13.29$, $P=0.001$ ) and orthophosphates (Kruskal-Wallis test,
$N=36, H=10.86, P=0.004)$ showed significant seasonal differences, as a consequence of higher vs. lower concentrations of nitrates and orthophosphates in spring, respectively (post-hoc test, $P<0.05$ ). Also, markedly higher concentrations of nitrates were found in JS $(1.59 \pm 0.11$ $\mathrm{mg} \mathrm{NO}_{3}^{-}$-N.L ${ }^{-1}$ ) compared to the other stations (Table 2a). The results of statistical analysis suggested that concentrations of food items, algae ( $\mathrm{Chl} a$ ) and detritus or POM, significantly differed along the longitudinal profile with pronounced higher values in lentic vegetated stations (Table 2a). POM shared from 21 to $33 \%$ in TSM, except for R1M, where its portion was $76 \%$.

Between the reservoirs R1 and R2, environmental parameters did not differ significantly (Mann-Whitney $U$ test, $P>0.05, N_{\mathrm{R} 1, \mathrm{R} 2}=12$ ). Increase of POM concentration from non-vegetated to vegetated stations in both reservoirs as well as Chl $a$ concentration in R1 gave rise to statistically significant differences (Mann-Whitney $U$ test, $P<0.05, N_{\mathrm{R} 1 \mathrm{~N}, \mathrm{R} 1 \mathrm{M}}=6$ ) shown in Table 3 .

\section{Zooseston in the Jankovac flow-through system}

The results of the statistical analyses suggested that zooseston abundance, biomass and biodiversity were significantly different in the longitudinal profile of the system. This was the case for the main investigated organism groups (Table 2b). The abundance (1-116 ind. $\left.\mathrm{L}^{-1}\right)$ and biomass $\left(0.1-357 \mu \mathrm{g} . \mathrm{DW} . \mathrm{L}^{-1}\right)$ of 


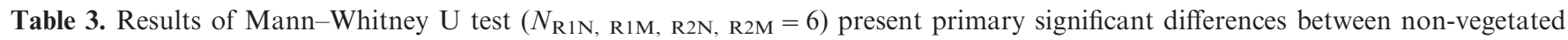
and vegetated stations for dominant taxa and main zooseston groups in reservoirs R1 and R2 in Jankovac flow-through system. Abbreviations: Chl $a$, chlorophyll $a$ concentration; POM, particulate organic matter; AFDW, ash-free dry weight.

\begin{tabular}{|c|c|c|c|c|c|c|c|c|}
\hline & $\begin{array}{c}\text { R1N } \\
\text { Mean } \pm \text { SD }\end{array}$ & $\begin{array}{c}\mathrm{R} 1 \mathrm{M} \\
\text { Mean } \pm \mathrm{SD} \\
\end{array}$ & $Z$ & $P$ & $\begin{array}{c}\mathrm{R} 2 \mathrm{~N} \\
\text { Mean } \pm \mathrm{SD}\end{array}$ & $\begin{array}{c}\mathrm{R} 2 \mathrm{M} \\
\text { Mean } \pm \mathrm{SD}\end{array}$ & $Z$ & $P$ \\
\hline$\overline{C h l} a\left(\mu \mathrm{g} . \mathrm{L}^{-1}\right)$ & $0.7 \pm 0.3$ & $2.0 \pm 1.6$ & -2.40 & * & $1.5 \pm 1.5$ & $1.4 \pm 1.1$ & -0.16 & ns \\
\hline POM (AFDW mg.m ${ }^{-3}$ ) & $0.6 \pm 0.4$ & $32.8 \pm 67.9$ & -2.72 & $* *$ & $0.6 \pm 0.3$ & $1.3 \pm 0.8$ & -2.24 & wo \\
\hline Colurella spp. (Ind. $\mathrm{L}^{-1}$ ) & $0.1 \pm 0.1$ & $0.3 \pm 0.2$ & -2.32 & $* *$ & $0.2 \pm 0.1$ & $0.2 \pm 0.1$ & 0.16 & $\mathrm{~ns}$ \\
\hline Lepadella patella $\left(\right.$ Ind. $\left.\mathrm{L}^{-1}\right)$ & $0.2 \pm 0.2$ & $0.6 \pm 0.4$ & -2.32 & $* *$ & $0.2 \pm 0.1$ & $0.3 \pm 0.3$ & -0.48 & \\
\hline Cladocerans (Ind.L ${ }^{-1}$ ) & $0.7 \pm 0.8$ & $14.0 \pm 22.8$ & -2.50 & $* *$ & $0.1 \pm 0.2$ & $6.1 \pm 12.5$ & -1.28 & \\
\hline Cladocerans large-bodied (Ind.L ${ }^{-1}$ ) & $0.1 \pm 0.2$ & $0.7 \pm 0.5$ & -2.72 & ** & $0.0 \pm 0.0$ & $0.4 \pm 0.6$ & -1.34 & \\
\hline Copepods (Ind. $\mathrm{L}^{-1}$ ) & $0.4 \pm 0.4$ & $8.3 \pm 4.5$ & -2.80 & $* *$ & $0.5 \pm 0.7$ & $5.7 \pm 9.2$ & -2.16 & \\
\hline Macrocyclops spp. (Ind. $\mathrm{L}^{-1}$ ) & $0.0 \pm 0.1$ & $0.5 \pm 0.2$ & -2.88 & $* * *$ & $0.0 \pm 0.1$ & $0.2 \pm 0.3$ & -1.75 & \\
\hline Nauplii (Ind. $L^{-1}$ ) & $0.1 \pm 0.1$ & $0.7 \pm 0.2$ & -2.88 & $* * *$ & $0.1 \pm 0.1$ & $0.5 \pm 0.5$ & -1.60 & \\
\hline Total zooseston (Ind.L ${ }^{-1}$ ) & $5.1 \pm 2.1$ & $41.3 \pm 40.7$ & -2.80 & $* *$ & $10.3 \pm 5.5$ & $20.2 \pm 23.3$ & -0.48 & \\
\hline Copepods $\left(\mu \mathrm{g} . \mathrm{L}^{-1}\right)$ & $0.6 \pm 0.7$ & $21.2 \pm 17.2$ & -2.80 & $* *$ & $0.5 \pm 1.0$ & $8.4 \pm 12.5$ & -2.16 & \\
\hline Taxa number & $14.5 \pm 3.3$ & $20.8 \pm 5.6$ & -2.17 & $* *$ & $14.3 \pm 4.8$ & $15.5 \pm 4.0$ & -0.40 & $\mathrm{~ns}$ \\
\hline
\end{tabular}

$* P<0.05 ; * * P<0.005 ; * * * P<0.001$
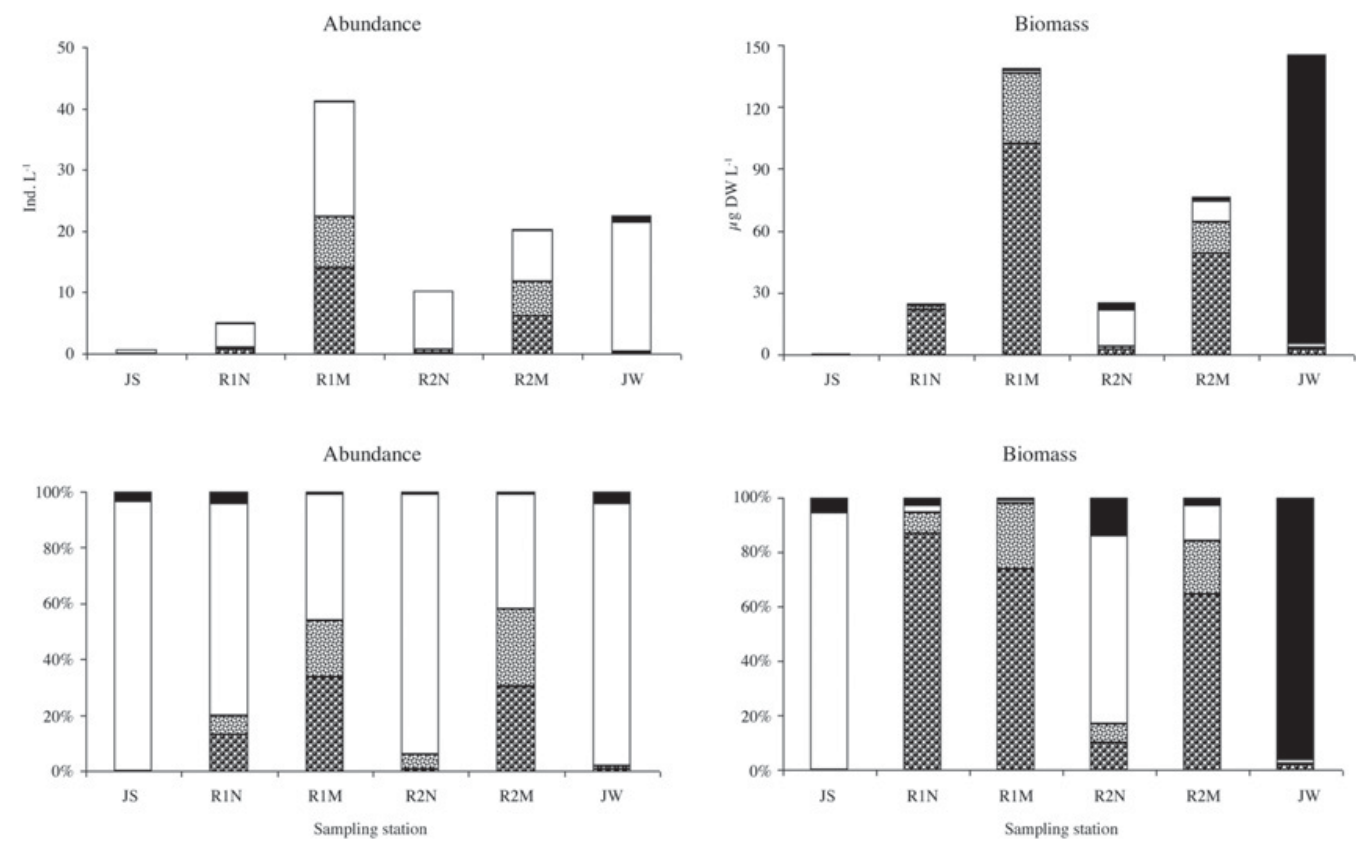

Fig. 2. Mean and relative abundance and biomass of Cladocera, Copepoda, Rotifera and heterogenic group of organisms in the investigated sampling stations of Jankovac Stream. Legend: JS, Jankovac Spring; R1N, Reservoir 1, non-vegetated area; R1M, Reservoir 1, vegetated area; R2N, Reservoir 2, non-vegetated area; R2M, Reservoir 2, vegetated area; JW, Jankovac Waterfall.

zooseton in all sampling stations of the Jankovac Stream were generally low, while zooseston biodiversity was high (Fig. 2). Altogether, 86 taxa were identified, 57 rotifers, 15 cladocerans, 8 copepods and 6 members of a heterogenic group of mostly benthic organisms (Table 4). Higher biodiversity was measured in vegetated (R1M 64 taxa and R2M 47 taxa) than in other stations (Tables $2 \mathrm{~b}$ and 3 ).

Rotifers prevailed in abundance (from 40 to $97 \%$ ) in all the investigated stations. In lentic stations, crustaceans prevailed in biomass, except for $\mathrm{R} 2 \mathrm{~N}$, where rotifers dominated (Fig. 2). The heterogenic group of organisms had the highest biomass in the lotic station JW, at the outflow of Jankovac Stream (Fig. 2). Considering the lifestyle, in the six investigated stations, $60 \%$ of the taxa were semi-planktonic, $36 \%$ euplanktonic and the remaining, only $1 \%$, belonged to benthic organisms (Table 4 ).

\section{Zooplankton community in lentic habitats}

\section{Reservoir 1}

In this reservoir, proximate to the stream inflow and prolonged WRT contrary to R2, significantly higher taxa 


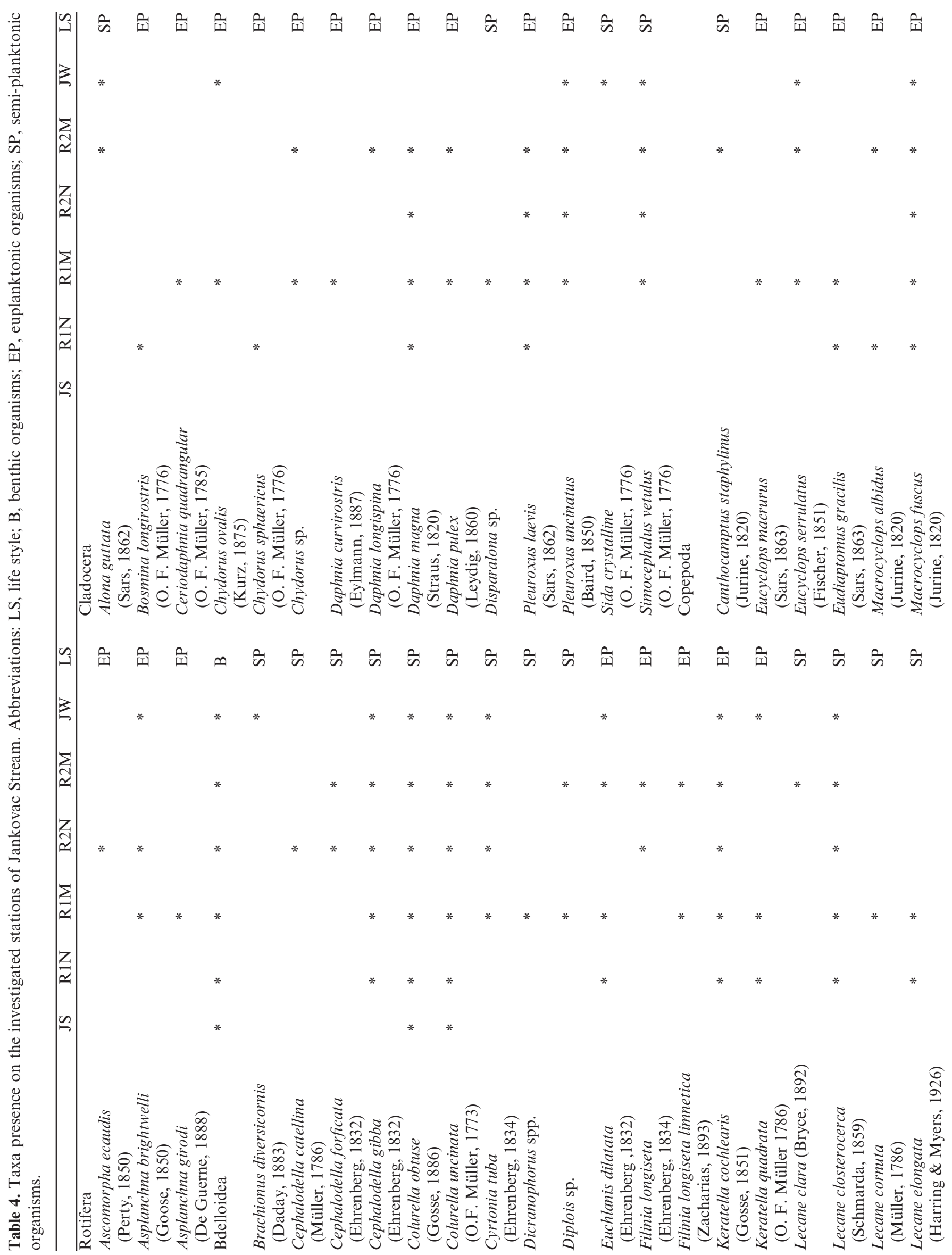




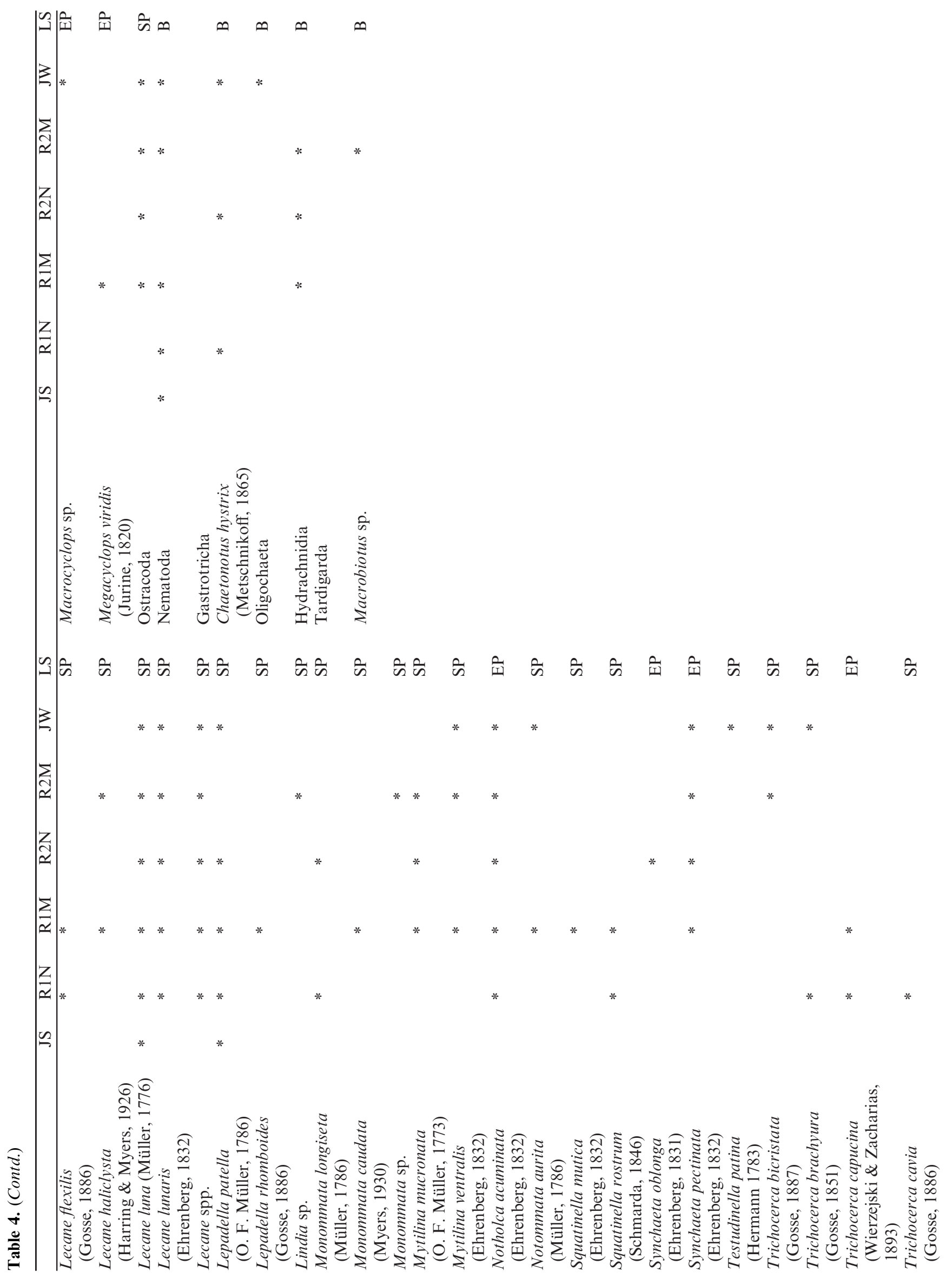




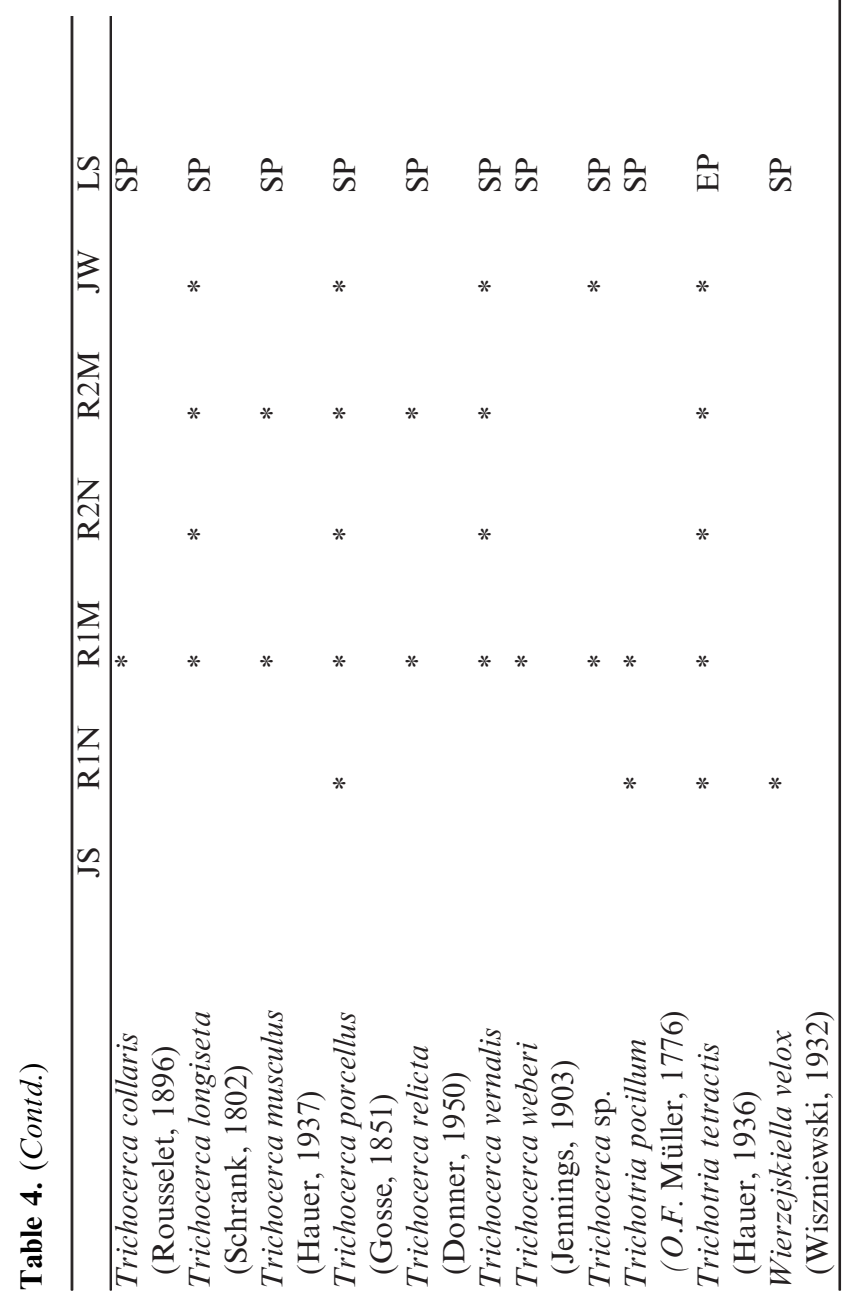

number was recorded in vegetated, R1M, than the nonvegetated, R1N station, 60 and 33 taxa, respectively (Tables 3 and 4). Rotifers, particularly the genera Lecane (8 taxa) and Trichocerca (11 taxa), had the highest contribution to the biodiversity in the vegetated area. Figure 2 shows that zooplankton abundance was dominated by rotifers (R1N 78\%; R1M 45\%), while cladocerans dominated the zooplankton biomass (R1N 60\%; R1M $73 \%$ ). Also, Figure 2 shows a positive shift in the abundance of all the investigated groups of organisms from non-vegetated to the vegetated stations, where abundance of cladocerans, copepods and total zooplankton significantly increased in the vegetated station, R1M (Table 3).

In the non-vegetated station $(\mathrm{R} 1 \mathrm{~N})$ cladocerans were represented by small-bodied species, e.g. Bosmina longirostris, while the vegetated station (R1M) was notably dominated by large-bodied cladocerans, i.e. Simocephalus vetulus (Table 3). Copepods, represented mainly by nauplii and adults of Macrocyclops fuscus, also significantly increased their abundance in the vegetated area (Table 3). Rotifers contributed mostly in abundance of the nonvegetated $(75 \%)$ and vegetated $(43 \%)$ station. However, the difference in rotifer abundance, between vegetated and non-vegetated stations were not significant (MannWhitney $U$ test, $P>0.05, N_{\mathrm{R} 1 \mathrm{~N}, \mathrm{R} 1 \mathrm{M}}=6$; Fig. 2). On the taxa level, semi-planktonic species from the genus Colurella and the species Lepadella patella achieved significantly higher abundance in R1M than in $\mathrm{R} 1 \mathrm{~N}$ (Table 3).

\section{Reservoir 2}

In this reservoir with shorter WRT compared to R1, non-vegetated (R2N) and vegetated (R2M) stations contained 33 and 46 taxa, respectively (Table 3 ). In spite of the higher abundance of large-bodied cladocerans, i.e. $S$. vetulus, in the vegetated than in non-vegetated station, a significant difference in the abundance was not established (Mann-Whitney $U$ test, $P>0.05, \quad N_{\mathrm{R} 2 \mathrm{~N}, \mathrm{R} 2 \mathrm{M}}=6$ ). Copepods were mostly represented by nauplii and less by adults of $M$. fuscus. Abundance and biomass of the copepods were significantly higher $(P<0.05)$ in the vegetated station, R2M (Fig. 2, Table 3). In non-vegetated station, R2N, rotifers prevailed in abundance $(97 \%)$ and biomass $(63 \%)$, but in relation to vegetated stations it was not significant (Mann-Whitney $U$ test, $P>0.05$, $N_{\text {R2N,R2M }}=6$ ).

In order to assess the interactions between environmental parameters and the main planktonic taxa in the reservoirs R1 and R2, a PCA was run. The first two axes explain $82 \%$ of the variance (Fig. 3). Axis 1 explains $56 \%$ of the variance and is negatively correlated with flow velocity and conductivity, while it is positively correlated with food resources (algae and detritus) and $\mathrm{pH}$ value. This axis explains the majority of interactions and according to the axis all investigated taxa were negatively affected by flow velocity. On the other hand, the concentration of food resources, detritus (POM) and algae 


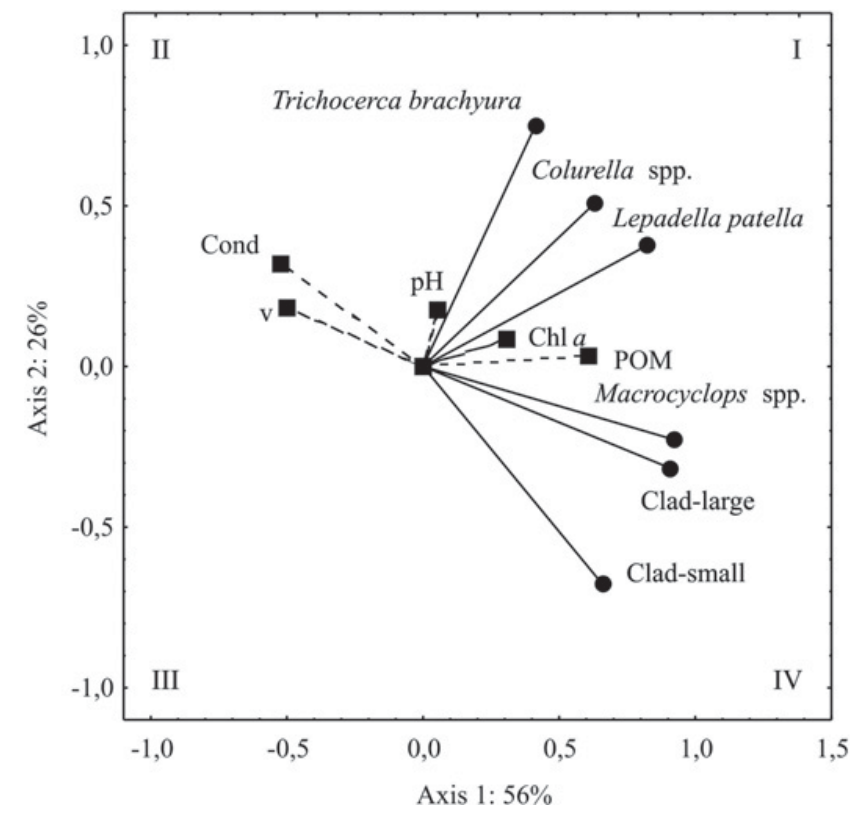

Fig. 3. PCA plot of the main zooplankton taxa abundance against environmental variables. Abbreviations by alphabetic order: Chl $a$, chlorophyll $a$ concentration; Clad-large, largebodied Cladocera; Clad-small, small-bodied Cladocera; Cond, conductivity; POM, particulate organic matter; v, flow velocity. Roman numerals mark quadrants.

(Chl $a$ ), had positive effects on all the taxa, and were higher in vegetated stations. These results are in concordance with the distribution of stations R1M and R2M in quadrants I and IV of PCA plot. Axis 2 explains $26 \%$ of the variance and positively correlates with flow velocity and conductivity. These interactions classified taxa as rheotolerant, rotifers, and rheointolerant, cladocerans and copepods. Moreover, it is in agreement with spatial prevalence of rotifers and crustaceans in R1M quadrant I and in R2M quadrant IV, respectively.

\section{Seston flux on the longitudinal profile}

The flux of TSM was highly related $(r=0.83 ; P<0.05$, $N=36$ ) to the flux of particulated organic matter (POM). The latter was positively influenced by zooseston flux $(r=0.38, P<0.05, N=36$ ). Figure 4 shows oscillations of TSM, POM and zooseston flux along the longitudinal profile of the system. These oscillations were significantly different between the stations (Kruskal-Wallis test, $H_{\mathrm{TSM}}=16.1, \quad P=0.007 ; \quad H_{\mathrm{POM}}=16.3, \quad P=0.006$; $\left.H_{\text {zooseston }}=18.1, P=0.003 ; N=36\right)$. TSM and POM fluxes achieved their peaks in R1M, while zooseston DW peaked in JW. Accordingly, the contribution of zooseston in POM flux increased along the longitudinal profile. Such a contribution was negligible in spring (JS), while it varied downstream from 3 to $30 \%$ in lentic habitats and reached a maximum of $57 \%$ in JW. It is assumed that a drift in the benthic organisms exhibited prominent contribution in zooseston flux at JW $(r=0.64, P<0.05, N=36)$.

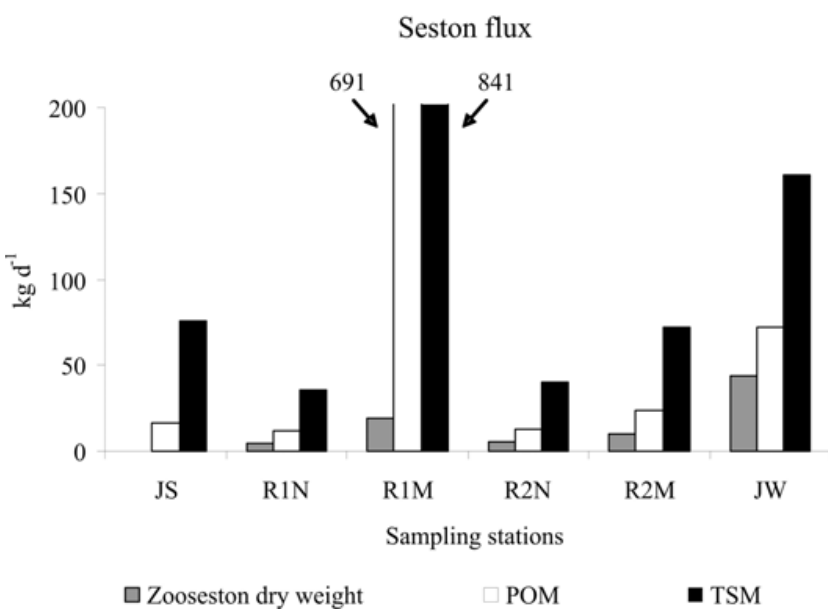

Fig. 4. Flux of the zoosenton dry weight biomass, POM and TSM along the Jankovac Stream longitudinal profile. Legend: JS, Jankovac Spring; R1N, Reservoir 1, non-vegetated area; R1M, Reservoir 1, vegetated area; R2N, Reservoir 2, nonvegetated area; R2M, Reservoir 2, vegetated area; JW, Jankovac Waterfall.

Passing through the lentic habitats, seston flux resulted in a significant increase of the phytoplankton ( $\mathrm{Chl} a$ ), cladocerans, copepods as well as euplanktonic organisms (Table 5a). Opposed to the inflow station (JS), at the outflow station (JW) significantly higher values of phytoplankton biomass $(\mathrm{Chl} a$ ), suspended POM, biomasses of euplanktonic, semi-planktonic and benthic organisms, and consequently total zooseston biomass were measured (Table 5b).

The PCA plot of interactions between the environmental parameters and the organisms in seston flux explained $65 \%$ of the variance (Fig. 5). Both axes (1 and 2) positively correlated with discharge, biomass of rotifers and heterogenic group, mainly benthic organisms and thus, concordantly resulted in increase of benthic organisms in seston flux. The biomass of the main zooseston groups as representatives of different life styles, negatively correlated with discharge and positively with food resources (AFDW and $\mathrm{Chl} a$ ), consequently explaining axis 1 (Fig. 5).

\section{Discussion}

The results of our study revealed scarcity of zooseston, but a wide spectrum of diversity caused by the prominent presence of rotifers in a submountain karst flow-through system. In reservoirs, zooplankton achieved higher diversity, abundance and biomass in vegetated than in nonvegetated areas. There, rotifers dominated in non-vegetated, while crustaceans dominated in vegetated stations. Statistical analyses suggested that zooplankton abundances in reservoirs were negatively affected by flow velocity and positively by food resources. Thus, seston flux consisted of rheotolerant zooplankton organisms, i.e. rotifers, and from drifted benthic organisms and bdelloid 
Table 5. Significant differences in seston flux (a) between lotic and lentic stretches and (b) inflow and outflow station in Jankovac Stream flow-through system analysed by Mann-Whitney $U$ test. Abbreviations: Q, discharge; Chl $a$, chlorophyll $a$ concentration; POM, particulate organic matter; TSM, total suspended matter.

\begin{tabular}{|c|c|c|c|c|}
\hline Flux $\left(\mathrm{kg} . \mathrm{d}^{-1}\right)$ & $\begin{array}{c}\text { Lotic } \\
\text { Mean } \pm \text { SD }\end{array}$ & $\begin{array}{c}\text { Lentic } \\
\text { Mean } \pm \text { SD }\end{array}$ & $Z$ & $P$ \\
\hline \multicolumn{5}{|c|}{ (a) Differences in discharge and seston flux between lotic $(N=12)$ and lentic $(N=24)$ stretches } \\
\hline$Q\left(\mathrm{~m}^{3} \cdot \mathrm{d}^{-1}\right)$ & $22398.4 \pm 24572.1$ & $28043.4 \pm 29680.6$ & 4.2 & $* * *$ \\
\hline TSM & $2.3 \pm 1.4$ & $12.6 \pm 35.8$ & 1.8 & * \\
\hline Cladocera biomass & $17640.6 \pm 40405.2$ & $320205.6 \pm 613732.0$ & -2.1 & $* *$ \\
\hline Copepoda biomass & $8496.5 \pm 8496.5$ & $116576.1 \pm 172771.5$ & -2.7 & $* *$ \\
\hline Euplanktonic organisms biomass & $48177.6 \pm 61658.9$ & $1114901.4 \pm 1864333.9$ & -3.5 & $* * *$ \\
\hline \multicolumn{5}{|c|}{ (b) Differences in discharge and seston flux between inflow $(\mathrm{NJS}=6)$ and outflow $(\mathrm{NJW}=6)$ station } \\
\hline Chl $a$ & $4296.9 \pm 4117.0$ & $36766.9 \pm 26053.9$ & -2.7 & $*$ \\
\hline Total zooseston biomass & $0.1 \pm 0.1$ & $72.4 \pm 113.9$ & -2.7 & $* *$ \\
\hline POM & $16.1 \pm 8.5$ & $44.3 \pm 39.3$ & -2.1 & $*$ \\
\hline Rotifera biomass & $1900.2 \pm 2968.2$ & $36856.9 \pm 26798.0$ & -2.7 & $* *$ \\
\hline Benthic organisms biomass & $543.7 \pm 1331.7$ & $66.3 \times 108 \pm 143.8 \times 108$ & -3.1 & $* *$ \\
\hline Euplanktonic organisms biomass & $21196.8 \pm 51039.3$ & $75158.4 \pm 63339.5$ & -2.2 & $* *$ \\
\hline Semi-planktonic organisms biomass & $264.4 \pm 619.3$ & $217267.2 \pm 367320.9$ & -2.9 & $* *$ \\
\hline
\end{tabular}

$* P<0.05 ; * * P<0.005 ; * * * P<0.001$

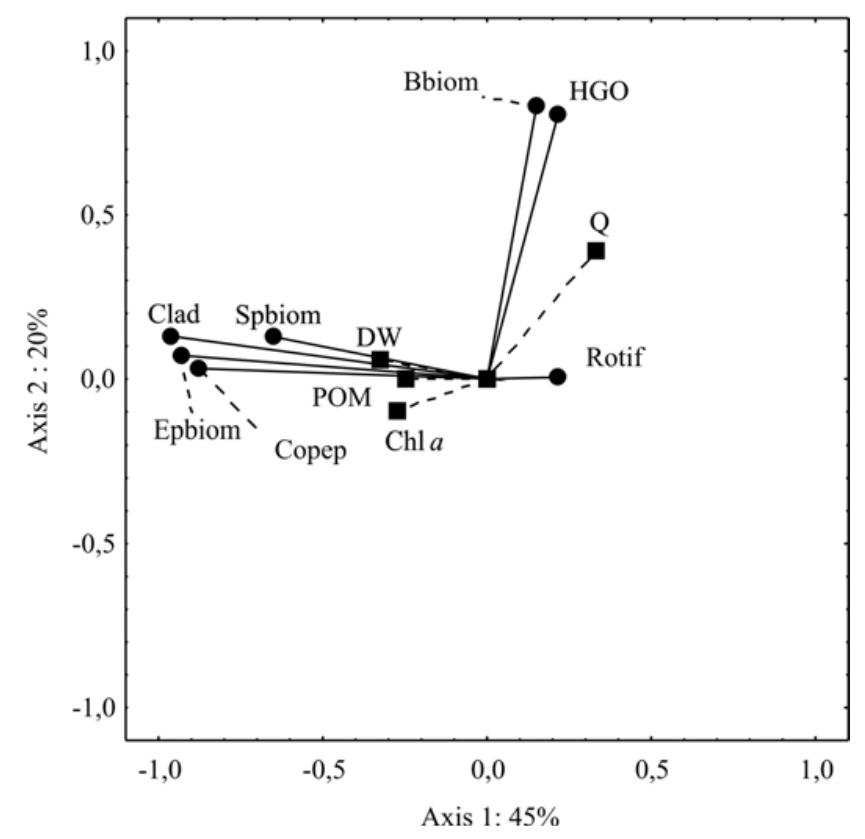

Fig. 5. PCA plot shows flux of the main groups in zooseston against environmental variables. Abbreviations: Q, discharge; Chla, chlorophyll $a$ concentration; POM, particulate organic matter; DW, dry weight; Clad, Cladocera biomass; Copep, Copepoda biomass; Rotif, Rotifera biomass; HGO, heterogenic group organisms biomass; Bbiom, benthic organisams biomass; Epbiom, euplanktonic organisms biomass; Spbiom, semiplanktonic organisms biomass.

rotifers, which are less susceptible to water current than cladocerans, as suggested by PCA.

The exclusive characteristics of Jankovac flow-through system are the elevated nitrate concentrations and the abundant stands of the submerged macrophyte $H$. vulgaris in the two man-made reservoirs. Also, recent tufa deposition on Skakavac barrier indicates the low trophic
State required for calcite precipitation (Srdoč et al., 1985; Špoljar et al., 2008). Higher nitrate levels can be explained by the proximity of a spring where nitrate-rich groundwater rises, which is common for spring waters, especially in the karst area (Malard et al., 1997). Nitrates declined in vegetated reservoirs probably due to macrophytes utilization causing significant downstream nitrate depletion.

The habitats of $H$. vulgaris are on the list of endangered species in Croatia (Nikolić and Topić, 2005). As the structural complexity is a main driver of biodiversity, more complex habitats generally contain more species (Van de Meutter et al., 2008). In Jankovac Stream, man-made reservoirs disrupt longitudinal continuum of running water and represent insurmountable barrier particularly for benthic macroinvertebrates (Bednarek and Hart, 2005). However these new habitats represent inocula of plankton abundance and diversity (Lair and ReyesMarchant, 1997; Zimmermann-Timm et al., 2007). Regarding hydrogeomorphology, the Jankovac reservoirs are comparable to the Plitvice Lakes. First, both hydrosystems are situated in sedimentary karst rocks and second, the lentic stretches dominate over lotic (Špoljar et al., 2007a, b). Furthermore, in both hydrosystems, high biodiversity has been established (Plitvice Lakes: 66 rotifer and 23 crustacean taxa; Jankovac reservoirs: 57 rotifer and 26 crustacean taxa). This high biodiversity in two small Jankovac reservoirs can be explained by the presence of high percentage of submerged macrophytes with complex habitat architecture, i.e. H. vulgaris. This is in accordance with the findings of other authors (Duggan et al., 2001; Kuczyńska-Kippen, 2005; Cazzanelli et al., 2008), who confirmed higher biodiversity in complex macrophyte stands. In Plitvice Lakes, the bottom is mostly covered with Chara spp., a complex habitat genus. Unfortunately, investigation or published data about zooplankton within its stands are not available. We hypothesise that submerged Chara stands promote diversity together with bryophyte communities on tufa barriers (Špoljar et al., 
2007b; Sertić Perić et al., 2011). Moreover, in Jankovac Stream, lotic stretches are also covered with bryophyte, which is assumed to contribute to species diversity (Špoljar et al., 2012).

\section{Reservoir and macrophyte habitats as a zooplankton source}

Flow velocity and WRT have been established as the key factors in the development of a plankton community in the running waters (Basu and Pick, 1996; Obertegger et al., 2010). In accordance to this, our results suggest that lentic habitats of the Jankovac flow-through system ensure the development of higher phytoplankton biomass and significant prevalence of semi-planktonic and euplanktonic small-bodied species, especially rotifers. Other authors noted the positive relationships between WRT and development of phytoplankton and zooplankton, i.e. rotifers and crustaceans (Basu and Pick, 1996; Walz and Welker, 1998; Rennella and Quiros, 2006; Obertegger et al., 2007).

Our results showed an increase of zooplankton diversity, abundance and biomass in vegetated area with lower current in comparison with non-vegetated area with higher current. Several mechanisms can explain the horizontal (non-vegetated vs. vegetated) distribution of zooplankton assemblages in reservoirs. First, non-uniform zooplankton distribution can be explained by different adaptations to water current. According to the PCA plot, we presumed that in Jankovac reservoirs, small- and largebodied cladocerans, as well as Mesocyclops avoid water current and belong to the group of rheointolerant organisms prevalent in the littoral vegetated zone, while rotifers belong to the group of rheotolerant organisms prevalent in the non-vegetated mainstream zone. Resistance of rotifers to water current in field and laboratory conditions has been attributed to their rapid heterogenetic reproduction, short generation time and less-susceptible fecundity in comparison with crustaceans as well as their resistance against sedimentation, which is contrary to larger-bodied organisms such as cladocerans (Stemberger and Gilbert, 1985; Weglenska and EjsmontKarabin, 1994; Holst et al., 1998; Burger et al., 2002; Sluss et al., 2008). Copepods are capable of avoiding water current due to fast movements or better handle turbulent conditions than cladocerans, but arguments also exist that they are sensitive to hydraulic stress (Lair and ReyesMarchant, 1997; Eriksson, 2002; Sluss et al., 2008). The significantly higher abundance/biomass of cladocerans, copepods and total zooseston in vegetated littoral stations of Jankovac reservoirs could be explained by the effect of a "zone of retentiveness" or a "storage zone" (Schiemer et al., 2001; Baranyi et al., 2002), where extended WRT allows zooplankton to grow and reproduce, and results in higher plankton abundance (Reynolds et al., 1991; Vadebouncoeur, 1994; Welker and Walz, 1998; Akbulut, 2004; Zimmermann-Timm et al., 2007).

Second, higher diversity, abundance and biomass of zooplankton in vegetated than in non-vegetated stations can be due to macrophyte coverage that provides more favourable habitat for zooplankton than open water because of the following: diverse habitats, richness of food quality and quantity, refuge from pelagial predators and competitors, and water movement (Bukvić et al. 1998; Basu et al., 2000; Burks et al., 2001a; Kuczyńska-Kippen and Nagengast, 2006). In our study, the PCA results confirm that all taxa included in the analysis, positively correlated with phytoplankton $(\mathrm{Chl} a)$ and suspended detritus particles (POM) as food resources, and that corresponded to the higher abundance in vegetated sampling stations. Similar results were obtained by Basu et al. (2000) in St. Lawrence River fluvial lakes, where zooplankton densities were higher in littoral zones than in the mainstream, and the plankton abundance was much higher in littoral macrophyte beds than in non-vegetated areas. Furthermore, we presumed that high percentage of macrophyte coverage and a shallow littoral zone induce the development and domination of semi- planktonic species as also established in Myriophyllum covered Budzyńskie Lake in Wielkopolski National Park, Poland (Kuczyńska-Kippen, 2003).

Third, biotic interactions, predation and competition increased under lentic conditions and decreased impact of losses due to advection (Baranyi et al., 2002). Opposite gradient in abundance ratio between rotifers and crustaceans in non-vegetated vs. vegetated area, could be explained by the biotic interactions. According to field observation and literature data (Mrakovčić et al., 2008), in Jankovac reservoirs, trout $(S$. trutta) is the main visual predator in non-vegetated area. It probably caused escape into vegetated areas and consequently higher abundance and biomass of large-bodied cladocerans and copepods in such habitats. Trout not only are known as opportunistic feeders that rely on benthic prey but also are partly planktivorous and could reduce large-bodied crustaceans, due to the size-selective predation (Fitzmaurice, 1979; Winder et al., 2003; Schabetsberger et al., 2006). Predation by newts, according to the literature, has weak impact on crustaceans, and there are more references about coexistence between newts and large crustaceans due to newts low digestion rate (Schabetsberger et al., 1996, 2006; Jersabek et al., 2001). Moreover, the higher relative abundance of rotifers in the non-vegetated compared to the vegetated areas could be a result of other biotic interactions, for instance competition with crustaceans (Bogdan and Gilbert, 1987; Cazzanelli et al., 2008) and avoidance of tactile predators, i.e. insect larvae, in the litoral zone (Burks et al., 2001b; Meerhoff et al., 2007; González-Sagrario et al., 2009).

\section{Seston advection}

Quantitative and qualitative seston structure is relevant as food resources for downstream benthic community (Habdija et al., 2004; Špoljar et al., 2007b) and organisms' dispersion (Sertić Perić et al., 2011). According to the data presented, the inflow station, JS, adjacent to spring was 
characterized by poor production and represented the initial state for downstream inoculation of seston with plankton and benthos. Downstream flux through the reservoirs implicated the remarkable enrichment of organic matter (POM and zooseston biomass), which originated mostly in vegetated stations and could be comparable to inshore influence on the fluvial lakes of the St. Lawrence River (Basu et al., 2000). In the vegetated lentic stations in Jankovac system, higher POM concentrations peaked prevalently from residuals of macrophyte stems, higher macroinvertebrate abundance and leaf litter. We presumed that the higher amount of organic matter on outflow, at JW, was a mixture of POM and benthic organisms from upstream bryophyte-covered bottom over the barrier and plankton enrichment through highly vegetated reservoirs (Sandlund, 1982; Suren, 1991). We consider substantial rotifer's abundance on the outflow station (JW), as sucus of specimens from reservoirs and drifting of benthic species, particularly bdelloids (Špoljar et al., 2007b).

The hydromorphological differences of Jankovac Stream channel maintained many microhabitats and seston biodiversity in a small-scale pattern, flowing from almost the uninoculated spring over bryophyte covered lotic stretches, towards reservoirs and finally over the bryophyte covered tufa barrier as Skakavac Waterfall. Results of this study indicate that hydrological features (flow velocity and WRT) and food resources (algae and detritus) mainly influenced zooseston longitudinal and horizontal assemblages within a flow-through system. Our results indicated that zooplankton horizontal assemblage could be shaped by the impact of biotic factors in submerse macrophyte covered reservoirs. Also, in our study, we included rotifers, which are often neglected in freshwater biotic interactions. Thus, the influence of biotic interactions, pelagial and littoral predation on horizontal distribution of zooplankton in reservoirs required elucidation and could be the objective of further investigation. High biodiversity on the invertebrate level and specific microhabitats on relatively small area deserve further investigation and monitoring and communication with the management in terms of appropriate protection and conservation.

Acknowledgements. This study was funded by the Papuk Nature Park and project 11900000001205 of the Ministry of Education, Science and Sport, Republic of Croatia. We thank the personnel of Papuk Nature Park for their help in administrative and field support during this investigation. We appreciate helpful and constructive comments of two anonymous referees for improvement of this manuscript.

\section{References}

Akbulut N.E., 2004. The determination of relationship between zooplankton and abiotic factors using canonical correspondence analysis (CCA) in the Ova Stream (Ankara/ Turkey). Acta Hydrochim. Hydrobiol., 32, 434-441.
APHA, 1985. Standard Methods for the Examination of Water and Waste (12th edn,), American Public Health Association, New York, 1268 p.

Baranyi C., Hein T., Holarek C., Keckeis S. and Schiemer F., 2002. Zooplankton biomass and community structure in a Danube River floodplain system: effects of hydrology. Freshwater Biol., 47, 473-482.

Basu B.K. and Pick F.R., 1996. Factors regulating phytoplankton and zooplankton biomass in temperate rivers. Limnol. Oceanogr., 41, 1572-1577.

Basu B.K., Kalff J. and Pinel-Alloul B., 2000. The influence of macrophyte beds on plankton communities and their export from fluvial lakes in the St. Lawrence River. Freshwater Biol., 45, 373-382.

Bednarek A.T. and Hart D.D., 2005. Modifying dam operations to restore rivers: ecological responses to Tennessee River dam mitigation. Ecol. Appl., 15, 997-1008.

Beklioglu M. and Jeppesen E., 1999. Behavioural response of plant-associated Eurycercus lamellatus (Ö.F. Müller) to different food sources and fish cues. Aquat. Ecol., 33, 167-173.

Bogdan K.G. and Gilbert J.J., 1987. Quantitative comparison of food niches in some freshwater zooplankton. Oecologia, 72, 331-340.

Breitig G. and von Tümpling W., 1982. Ausgewaehlte Methoden der Wasseruntersuchung, Band II. Biologische, mikrobiologische und toxikologische Methoden, VEB Gustav Fischer Verlag, Jena, 579 p.

Bukvić I., Kerovec M., Plenkovic A. and Mrakovcic M., 1998. Impact of silver and bighead carp (Cyprinidae) on plankton and water quality in fish ponds. Biologia, Bratislava, 53, 145-157.

Burger D.F., Hogg I.D. and Green J.D., 2002. Distribution and abundance of zooplankton in the Waikato River, New Zeland. Hydrobiologia, 479, 31-38.

Burks R.L., Jeppesen E. and Lodge D.M., 2001a. Littoral zone structures as Daphnia refugia against fish predators. Limnol. Oceanogr., 46, 230-237.

Burks R.L., Jeppesen E. and Lodge D.M., 2001b. Pelagic prey and benthic predators: impact of odonate predation on Daphnia. J. N. Am. Benthol. Soc., 20, 615-628.

Castro B.B., Antunes S.C., Pereira R., Soares A.M.V.M. and Gonçalves F., 2005. Rotifer community structure in three shallow lakes: seasonal fluctuations and explanatory factors. Hydrobiologia, 543, 221-232.

Cazzanelli M., Warming T.P. and Christoffersen K.S., 2008. Emergent and floating-leaved macrophytes as refuge for zooplankton in a eutrophic temperate lake without submerged vegetation. Hydrobiologia, 605, 113-122.

Descy J.P., 1993. Phytoplankton composition and dynamics in the river Meuse (Belgium). Arch. Hydrobiol. Suppl., 78, 225-245.

Duggan I.C., Green J.D., Thompson K. and Shiel R.J., 2001. The influence of macrophytes on the spatial distribution of littoral rotifers. Freshwater Biol., 46, 777-786.

Dumont H.J., van de Velde I. and Dumont S., 1975. The dry weight in a selection of Cladocera, Copepoda and rotifera from the plankton, periphyton and benthos of continental waters. Oecologia, 19, 75-92.

Einsle U., 1993. Crustacea, Copepoda, Calanoida und Cyclopoida, Gustav Fischer Verlag, Berlin, 208 p.

El-Shabrawy G.M. and Dumont H.J., 2003. Spatial and seasonal variation of the zooplankton in the coastal zone 
and main khors of Lake Nasser (Egypt). Hydrobiologia, 491, 119-132.

Eriksson A.I., 2002. Can predation by net-spinning caddis larvae (Trichoptera: Hydropsyche siltalai) cause longitudinal changes in zooplankton species composition in lake-outlet streams?Arch. Hydrobiol., 153, 231-244.

Estlander S., Nurminen L., Olin M., Vinni M. and Horppila J., 2009. Seasonal fluctuations in macrophyte cover and water transparency of four brown-water lakes: implications for crustacean zooplankton in littoral and pelagic habitats. Hydrobiologia, 620, 109-120.

Fitzmaurice P., 1979. Selective predation on Cladocera by brown trout Salmo trutta L. J. Fish. Biol., 15, 521-525.

Gliwicz Z.M. and Rykowska A., 1992. "Shore avoidance" in zooplankton: a predator-induced behaviour or predatorinduced mortality? J. Plankton Res., 14, 1331-1342.

González-Sagrario, M.A., Balseiro E., Ituarte R. and Spivak E., 2009. Macrophytes as refuge or risky area for zooplankton: a balance set by littoral predacious macroinvertebrates. Freshwater Biol., 54, 1042-1053.

Habdija I., Primc-Habdija B., Matoničkin R., Kučinić M., Radanović I., Miliša M., and Mihaljević Z., 2004. Current velocity and food supply as factors affecting the composition of macroinvertebrates in bryophyte habitats in Karst running water. Biologia, 59, 577-593.

Hart D.D. and Finelli C.M., 1999. Physical-biological coupling in streams: The pervasive effects of flow on benthic organisms. Annu. Rev. Ecol. Syst., 30, 363-95.

Höll K., 1986. Wasser Untersuchung, Beurteilung, Aufbereitung, Chemie, Bakteriologie, Virologie, Biologie (7th edn.), Walter de Gruyter Verlag, Berlin, 393 p.

Holst H., Zimmermann H., Kausch H. and Koste W., 1998. Temporal and spatial dynamics of planktonic rotifers in the Elbe Estuary during spring. Estuar. Coast. Shelf Sci., 47, 261-273.

Horppila J. and Nurminen L., 2005. Effects of different macrophyte growth forms on sediment and $\mathrm{P}$ resuspension in a shallow lake. Hydrobiologia, 545, 167-175.

Jeppesen E., Jensen J.P., Sondergaard M., Lauridsen T., Pedersen J.P. and Jensen L., 1997. Top-down control in freshwater lakes: the role of nutrient state, submerged macrophytes and water depth. Hydrobiologia, 342/343, 151164.

Jersabek C.D., Brancelj A., Stoch F. and Schabetsberger R., 2001. Distribution and ecology of copepods in mountainous regions of the Eastern Alps. Hydrobiologia, 453/454, 309-324.

Kalff J., 2002. Limnology: Inland Water Ecosystems, Prentice Hall, Upper Saddle River, New Jersey, 592 p.

Kuczyńska-Kippen N., 2003. The distribution of rotifers (Rotifera) within a single Myriophyllum bed. Hydrobiologia, 506, 327-331.

Kuczyńska-Kippen N., 2005. On body size and habitat selection in rotifers in a macrophyte-dominatedlake Budzyńskie, Poland. Aquat. Ecol., 39, 447-454.

Kuczyńska-Kippen N. and Nagengast B., 2006. The influence of the spatial structure of hydromacrophytes and differentiating habitat on the structure of rotifer and cladoceran communities. Hydrobiologia, 559, 203-212.

Lair N., 1980. The rotifer fauna of the River Loire (France), at the level of the nuclear power plants. Hydrobiologia, 73, 153-160.
Lair N. and Reyes-Marchant P., 1997. The potamoplankton of the Middle Loire and the role of the "moving littoral" in downstream transfer of algae and rotifers. Hydrobiologia, 356, 33-52.

Lau S.S.S. and Lane S.N., 2002. Nutrient and grazing factors in relation to phytoplankton level in a eutrophic shallow lake: the effect of low macrophyte abundance. Water Res., 36, 3593-3601.

Lauridsen T. and Lodge D.M., 1996. Avoidance by Daphnia magna of fish and macrophytes: chemical cues and predatormediated use of macrophyte habitat. Limnol. Oceanogr., 4, 794-798.

Malard F., Turquin M.J. and Magniez G., 1997. Filter effect of karstic spring ecotones on the population structure of the hypogean amphipod Niphargus virei. In: Gilbert J., Mathieu J. and Fournier F. (eds.), Groundwater/Surface Water Ecotones: Biological and Hydrological Interactions and Management Options, Cambridge University Press, Cambridge, 40-50.

Malley D.F., Lawrence S.G., MacIver M.A. and Findlay W.J., 1989. Range of variation in estimates of dry weight for planktonic Crustacea and Rotifera from temperate North American lakes. Can. Tech. Rep. Fish. and Aquat. Sci., 1666, $1-49$.

Margaritora F., 1983. Cladoceri (Crustacea: Cladocera). Guide per il Reconoscimiento delle Specie Animali delle Acque Interne 22, Consiglio Nazionale delle Ricerche, Roma, 167 p.

Meerhoff M., Fosalba C., Bruzzone C., Mazzeo N., Noordoven W. and Jeppesen E., 2006. An experimental study of habitat choice by Daphnia: plants signal danger more than refuge in subtropical lakes. Freshwater Biol., 51, 1320-1330.

Meerhoff M., Iglesias C., De Mello F.T., Clemente J.M., Jensen E., Lauridsen T.L. and Jeppesen E., 2007. Effects of habitat complexity on community structure and predator avoidance behaviour of littoral zooplankton in temperate versus subtropical shallow lakes. Freshwater Biol., 52, 1009-1021.

Mrakovčić M., Mihaljević Z., Mustafić P., Zanella D., Ćaleta M. and Marčić Z., 2008. Ichthyofauna and macroinvertebrates in major stream of Papuk. Nature Park. Internal report, in Croatian, $80 \mathrm{p}$.

Nikolić T. and Topić J. 2005. Red Book of Vaskular Flora of Croatia. Ministry of Culture, The State Institute for Nature Protection, Zagreb, 693 p.

Nusch E.A., 1980. Comparison of different methods for chlorophyll and phaeopigment determination. Arch. Hydrobiol., 14, 14-36.

Obertegger U., Borsato A. and Flaim G., 2010. Rotifercrustacean interactions in a pseudokarstic lake: influence of hydrology. Aquat. Ecol., 44, 121-130.

Obertegger U., Flaim G., Braioni M.G., Sommaruga R., Corradini F. and Borsato A., 2007. Water residence time as a driving force of zooplankton structure and succession. Aquat. Sci., 69, 575-583.

Rennella A.M. and Quiros R., 2006. The effects of hydrology on plankton biomass in shallow lakes of the Pampa Plain. Hydrobiologia, 556, 181-191.

Reynolds C.S., Carling P.A. and Beven K.J., 1991. Flow in river channels: new insights into hydraulic retention. Arch. Hydrobiol., 121, 171-179.

Sandlund O.T., 1982. The drift of zooplankton and microzoobenthos in the river Strandaelva, western Norway. Hydrobiologia, 94, 33-48. 
Schabetsberger R., Brozek S., Entachter K., Jersabek C. and Goldschmid A., 1996. Effects of temperature and body weight on gastric evacuation rates of Alpine newt (Triturus alpestris) larvae. Herpetol. J., 6, 75-81.

Schabetsberger R., Grill S., Hauser G. and Wukits P., 2006. Zooplankton successions in neighboring lakes with contrasting impacts of amphibian and fish predators. Int. Rev. Hydrobiol., 91, 197-221.

Schiemer F., Keckeis H., Reckendorfer W. and Winkler G., 2001. The "inshore retention concept" and its significance for large rivers. Arch. Hydrobiol. Suppl., 135, 509-516.

Sertić Perić M., Miliša M., Primc-Habdija B. and Habdija I., 2011. Seasonal and fine-scale spatial patterns of drift and seston in a tufa-depositing barrage hydrosystem. Fund. Appl. Limnol., 178, 131-145.

Sluss T.D., Cobbs G.A. and Thorp J.H., 2008. Impact of turbulence on riverine zooplankton: a Mesocosm experiment. Freshwater Biol., 53, 1999-2010.

Špoljar M., Habdija I. and Primc-Habdija B., 2007a. Transport of seston in the karstic hydrosystem of the Plitvice Lakes (Croatia). Hydrobiologia, 579, 199-209.

Špoljar M., Primc-Habdija B. and Habdija I., 2007b. The Influence of the lotic and lentic stretches on the zooseston flux through the Plitvice Lakes (Croatia). Ann. Limnol. - Int. J. Lim., 43, 29-40.

Špoljar M., Dražina T., Ostojić A., Kralj Borojević K., Šargač J., Stafa D. and Meseljević M., 2008. Travertine biocenosys of Jankovac Waterfall, Papuk Nature Park. Internal report, in Croatian, 73 p.

Špoljar M., Dražina T., Ostojić A., Miliša M., Gligora Udovič M. and Štafa D., 2012. Bryophyte communities and seston in a karst stream (Jankovac Stream, Papuk Nature Park, Croatia). Ann. Limnol. - Int. J. Lim., 48, 125-138.

Srdoč D., Horvatinčić N., Obelić B., Krajcar-Bronić I. and Sliepčević A., 1985. Calcite deposition processes in karst waters with special emphasis on the Plitvice lakes, Yugoslavia. Carsus Jugosl., 11, 101-204.

Stemberger R.S. and Gilbert J.J., 1985. Body size, food concentration and population growth in planktonic rotifers. Ecology, 66, 1151-1159.

Suren A.M., 1991. Bryophytes as invertebrate habitat in two new Zeland alpine streams. Freshwater Biol., 26, 399-418.

Vadebouncoeur Y., 1994. Longitudinal dynamics of seston concentration and composition in a lake outlet stream. J. N. Am. Benthol.Soc., 13, 181-189.

Van de Meutter F., Cottenie K. and De Meester L., 2008. Exploring differences in macroinvertebrate communities from emergent, floating-leaved and submersed vegetation in shallow ponds. Fund. Appl. Limnol., 173, 47-57.

Voigt M. and Koste W., 1978. Die Rädertiere Mitteleuropas, Gebrüder Borntraeger., Berlin, Stuttgart, 673 p.

Walz N. and Welker M., 1998. Plankton development in a rapidly flushed lake in the river Spree system (Neuendorfer See, Northeast Germany). J. Plankton Res., 20, 2071-2087.

Węglenska T. and Ejsmont-Karabin J., 1994. The short and long term variability of the zooplankton structure in the Zagrzyński reservoir. Arch. Hydrobiol., 40, 117-126.

Welker M. and Walz N., 1998. Can mussels control the plankton in rivers? - A planktological approach applying a Lagrangian sampling strategy. Limnol. Oceanogr., 43, 753-762.

Winder M., Bürgi H.R. and Spaak P., 2003. Mechanisms regulating zooplankton populations in a high-mountain lake. Freshwater Biol., 48, 795-809.

Zimmermann-Timm H., Holst H. and Kausch H., 2007. Spatial dynamics of rotifers in a large lowland river, the Elbe, Germany: how important are retentive shoreline habitats for the plankton community? Hydrobiologia, 593, 49-58. 